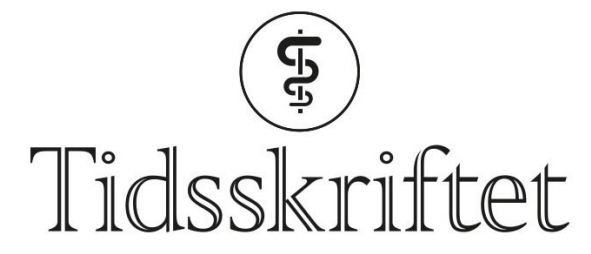

DEN NORSKE LEGEFORENING

\title{
Stabile boforhold og sosial støtte kan bedre hivbehandling
}

FRA ANDRE TIDSSKRIFTER

KETIL SLAGSTAD

Tidsskriftet

Sosiale forhold påvirker etterlevelse av legemiddelbehandling for hivinfeksjon hos kvinner som bruker heroin i Tanzanias hovedstad.

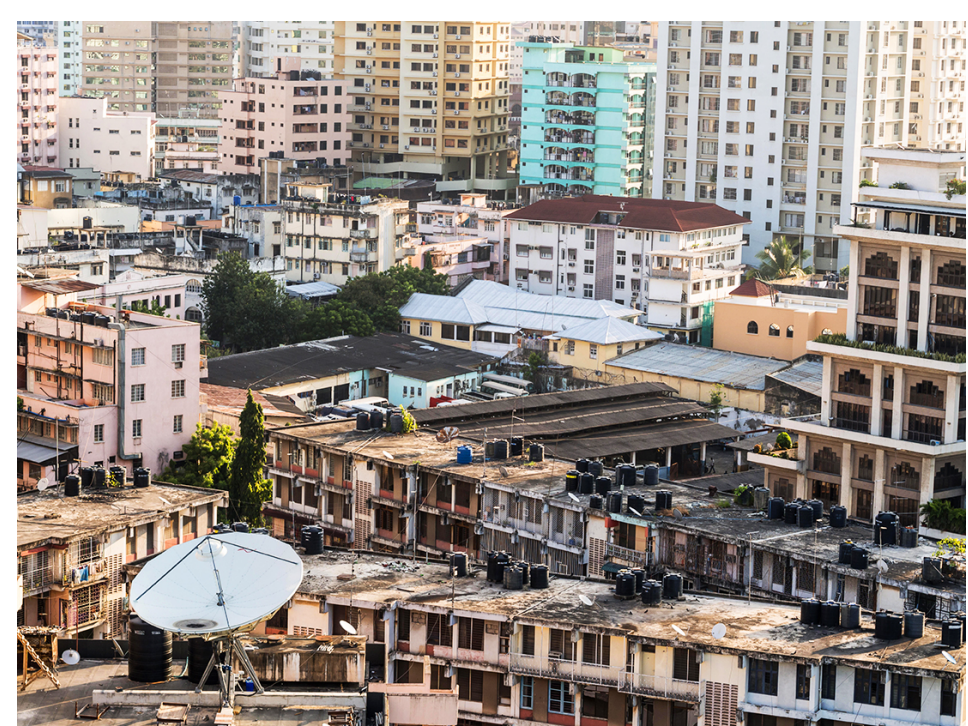

Tanzanias hovedstad, Dar es Salaam. Illustrasjonsfoto: Magdalena Paluchowska / Alamy Stock Photo

Blant Dar es Salaams 6,7 millioner innbyggere bruker 300 ooo personer rusmidler, og hovedstaden er et viktig knutepunkt for omsetting av rusmidler. Over $60 \%$ av kvinner som injiserer rusmidler i Tanzania, lever med hiv.

I en studie som nylig er publisert i tidsskriftet Social Science \& Medicine, ble det foretatt kvalitative intervjuer med 30 kvinner i Dar es Salam som brukte heroin og levde med hiv. Intervjuene ble analysert med databasert teoriutvikling (eng. grounded theory) for å identifisere hvordan dagsrytmer og sosiale rom påvirket etterlevelse av antiretroviral legemiddelbehandling (1).

Ustabile boforhold og hjemløshet, stor mobilitet, sosialt stigma og skiftende dagsruter som følge av sexarbeid eller heroinbruk var noen av de viktigste grunnene til at kvinnene ikke klarte å etterleve antiretroviral behandling. Abstinenssymptomer og manglende penger til mat var andre grunner til at det var vanskelig å ta legemidlene. Praktisk og emosjonell støtte fra familie og venner var viktige grunner til at kvinnene klarte å ta legemidlene som 
planlagt, for eksempel ved å få følge til legetimen eller ved å bli minnet på å ta pillene.

- Denne studien illustrerer betydningen av å ta hensyn til folks tidsgeografiske livsbetingelser hvis man skal lykkes med behandling og bedre folks helse, sier Kåre Moen, som er førsteamanuensis ved Institutt for helse og samfunn ved Universitetet i Oslo.

- Den detaljerte analysen av dagliglivet til heroinbrukerne viste hvordan tid og rom satte begrensninger for muligheten til å ta hivmedisiner regelmessig. Å etterleve behandlingen var avhengig av forhold som var vanskelig å kontrollere, sier Moen.

- Selv om studien gir god innsikt i forhold som er spesielle for en bestemt populasjon med en bestemt sykdom i et bestemt land, er den inspirerende og har stor overføringsverdi til andre situasjoner der fagfolk skal utvikle behandlingsopplegg, sier Moen.

\section{LITTERATUR:}

1. Saleem HT, Likindikoki S, Silberg C et al. Time-space constraints to HIV treatment engagement among women who use heroin in Dar es Salaam, Tanzania: A time geography perspective. Soc Sci Med 2020; 268: 113379. [PubMed][CrossRef]

Publisert:30. november 2020. Tidsskr Nor Legeforen. DOI: 10.4045/tidsskr.20.0907

(C) Tidsskrift for Den norske legeforening 2020. Lastet ned fra tidsskriftet.no 